\title{
HALK HİKÂYESİ İLE MODERN ROMAN ARASINDA KALMIŞ BİR İZMİR ROMANI: AĞANIN OĞLU
}

\section{ÖZ}

Muzaffer ÇANDIR ${ }^{1}$

Ağanın Oğlu romanı Raif Nezih Atakul tarafından 1926 yılında İmir'de yayımlanmıștır. Ebat olarak uzun hikâye, kısa roman tarzında yazılan eser hâlâ yeni harflerle basılmamıştır. İzmir'de basılan az sayıdaki romanlardan biri olan bu eser, edebiyat dünyası tarafindan tanınmamaktadır. Bu eserin önemi, hem tarihi halk romanı olması, hem de halk hikâyesi formuna yakın bir șekilde kurgulanmıs olmasıdır. Yer yer halk hikâyesi özelliği de gösteren eser, bu özelliği ile halk hikâyesi ile modern roman arasında değerlendirilmesi gereken bir özelliğe sahiptir. İçinde yazıldığı yıllardaki İzmir şehrinin yaşam özelliklerinin de bulunduğu romanda baba oğul iki ağanın hayatı üzerinden kadınların ihaneti ve onlara güvenilmemesi gerektiği teması öne çıkarılmaktadır.

Anahtar Sözcükler: Raif Nezih Atakul, Halk Romanı, İzmir'de

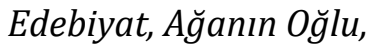

\section{AN IZMIR NOVEL THAT IS STUCK BETWEEN FOLK TALE AND MODERN NOVEL: AĞANIN OĞLU}

\section{ABSTRACT}

The novel Aganin-Oglu was published by Raif Nezih Atakul in 1926 in Izmir. In terms of its size it is a long story written in a style of a short novel, and it has still been not published in the new alphabet. Only a few novels were published in Izmir and this novel is one of them and it was recognized by the world of literature. The importance of this writing is that it is a historical folk novel and at the same time it is a folk story. Partly a folk story, it can be identified as a text between a folk story and a modern novel. The main story line of this novel proceeds through the life of two landowners, father and son, and the betrayal of women and that one must never trust them, while describing the lifestyle of Izmir in those years when the action of the novel takes place.

Key Words: Raif Nezih Atakul, folk novel, literature in Izmir, Ağanın Ŏglu.

\footnotetext{
${ }^{1}$ Yrd. Doç. Dr. Manisa Celal Bayar Üniversitesi Türk Dili ve Edebiyatı Bölümü, mail: candir45@yahoo.com
} 


\section{GíRiş}

Bu makalede bütün toplumların en çok ilgi gösterdiği bir anlatı olan modern romanın ilk şekli destandan başlayarak halk hikâyesine, oradan da modern öyküye evrilme süreci anlatılacak, sonra da bir İzmir romanı olan Ağanın Oğlu ${ }^{2}$ adlı kısa romanın halk hikâyesine benzeyen tarafları ortaya konmaya çalışılacaktır.

Makaleye böyle başlamamızın nedeni, Ağanın Oğlu romanının hem uzun hikâyeye, daha çok da arasındaki türkülere ve anlatım şekline bakılınca bir halk hikâyesine benzemesidir. $\mathrm{Bu}$ durum makalenin devamında örneklerle ayrıntılı olarak ortaya konacaktır.

Göçebe hayatının anlatısı olan destanlar insanların hayatta kalmak için tabiat şartlarıyla ve başka topluluklarla yaptığı mücadeleler sonucunda ortaya çıkmıştır. Bu mücadeleler anlatılırken toplumun geneli yerine bir kahraman öne çlkarılmış, toplumların varoluş mücadeleleri bu kahramanın etrafında anlatılmıştır. Destan tipleri toplumun ortak tipleridir. "Toplum, daha önce yaşamış ve zihinlerde iz bırakmış tiplerin bütün iyi özelliklerini kendi dönemine taşımış ve bu dönemin parlayan tipine bunları yerleştirmiştir." 3

Destan kahramanı yalnız kendi özelliklerine değil, daha önce yaşamış kahramanların özelliklerine de sahiptir. Toplum, idealize ettiği bu kahramana, kendisinde olmasa bile bütün olumlu özellikleri vermekte cömert davranır. Aslında bu özellikler kahramanın şahsında toplansa da toplumun ortak özellikleridir. Buradaki kahraman, bu özelliklerin yalnız bir taşıyıcısıdır. Toplumlar bu özellikleri bir kahramanın ağzından anlatarak gelecek nesillere hem nasıl olunması gerektiğini hem de kendi toplumsal erdemlerini ifade etmiş olurlar.

Buradaki destan kahramanına atfedilen özellikleri bir çeşit destan diyebileceğimiz evliya menkıbelerinde de görebiliriz. Tasavvuf edebiyatında menkıbe destandan ayrı bir tür olsa da olağanüstü dini ve ahlaki özelliklerin bir insanda toplanması bakımından destana benzetilebilir. Menkıbelerdeki bu abartılı dini ve ahlaki özellikler, toplumun olmasını istediği, ancak toplumun genelinde olabilecek özelliklerdir.

Kurmaca metinlerden hikâye ve romanın ilk örneklerinin destanlar olduğu bilinmektedir. Sonraki yıllarda destan yerini diğer anlatı türlerinden masal, efsane ve halk hikâyesine bırakmıştır.

\footnotetext{
2 Raif Nezih (Atakul), Ağanın Oğlu, Bilgi Matbaası, İzmir 1926. $78 \mathrm{s.}$

3 Sevtap Yazar, "Destan, Halk Hikâyesi ve Masal Arasındaki İlișkiler ve Bu Unsurların Destanlara Yansıması", s. 7, (http://web.deu.edu.tr/ ilyas/edebiyat/destan.htm)
} 
Halkın düş gücü ile devamlı büyüyen ve zenginleșen bu geleneksel türler, hemen her toplumda vardır ve halkın kurmaca anlatı ihtiyacını karşılamaktadır. Bu halk anlatıları Divan şairlerince edebiyattan sayılmayıp ikinci plana atılınca kendine daha çok köy ve kasabalarda yer bulabilmişlerdir.

Modern roman tahlillerinde ele alınan kahramanlar analiz edilirken "idealize edilmiș tip" diye bir sınıflama yapılır. Bu idealize tip, aslında destan ve menkıbelerdeki abartılı kahramanın bir benzeridir. Aralarındaki fark eski türlerdeki kahramanlarda abartının dozunun ayarlanamamasıdır.

Zamanla yarı göçebe veya yerleşik düzene geçen toplumda kişisel kahramanlıklar yerini iç çatışmalara ve insanların bireysel sorunlarına bırakır. Yerleșik düzenin eserleri konu itibariyle daha çok bireysel duygulardır ve bunun başında da aşk konusu gelir. Halk edebiyatının halk hikâyeleri olarak bildiğimiz alt unsuru, bu gelişimin ürünleridir. Genellikle nazım ve nesir karıșık olarak söylenen bu hikâyelerin iç motifleri eski anlatmalar olan destan ve masaldan alınmış malzemelerdir.

Halk hikâyelerini destandan ayıran en belirgin özellikler, tarihi bir olayın olmaması, nazım - nesir karışık olması, şahısların ve çevrenin gerçeğe yakın tasviri ile aşk konusunun ağırlıklı olarak anlatılmasidır.

Hikâye terimi ilk defa dokuzuncu yüzyılda Cehiz tarafından kullanılmış olup; Arapça hakeve kökünden türeyen bu kelime, "anlatma, benzetme, tarih, destan, kıssa, masal, rivayet" manalarını ifade eder. Destan ile hikâye arasında bir geçiş kabul edilen Dede Korkut'ta "boy" olarak ifade edilen hikâye kavramı Türkiye'de değişik terimlerle isimlendirilmiştir. "Anadolu sahasında kullanılan hikâye teriminden başka, türküsüz hikâyelere kara hikâye, kısa hikâyelere kıssa, serküşte (sergüzeștten bozma) dendiği bilinmektedir." 4

Ahmet Saçkesen halk hikâyelerini, destandan modern romana geçiş aşamasında ortaya çıkmış bir tür olarak değerlendirmek doğru olacaktır5 derken, Boratav: "Halk hikâyeleri destanîleşmiş masallar veya destanîliklerini kaybetmiş masallarla çok karışmış masallar" veya "eskiden destanların gördükleri vazifeleri üzerine almış yeni ve

${ }^{4}$ Ali Berat Alptekin, Halk Hikâyelerinin Motif Yapısı, Ankara, 2003, s.3.

${ }^{5}$ Ahmet Saçkesen, İzmir'de Yaşayan Âşıklardan Derlenen Halk Hikâyeleri Üzerine Bir Araștırma, Ege Üniversitesi, Sosyal Bilimler Enstitüsü, 2003, s. 17. (Yayınlanmamış Yüksek Lisans Tezi) 
orijinal bir nev'in mahsulleri"6 olarak değerlendirir. Otto Spies de "Halk hikâyeleri, bir sevgiliyi elde etme yolundaki maceraları anlatan masallardır"7 diyerek farklı bir tanım getirir.

Halk hikâyeleri, destan döneminin sonunda ortaya çılkmış, eserlerdir. Halk hikâyelerinde tarihi olayların daha az olması, nazımnesir karışık bir yapının bulunması, zamanla nesir kısmının ağırlık kazanması, olaylar ve kişiler bakımından gerçeğe daha yakın olması bunları destanlardan ayıran en önemli özelliklerdir. Bu durumdan hareketle halk hikâyeleri destanla roman arasındaki geçiş döneminde ortaya çıkan "epico-romanesque" ürünler olarak adlandırılabilir. Halk hikâyeleri gerek konu bakımından gerekse şekil bakımından hem epik eserlerin özelliklerini taşımakta hem de modem romandaki tip ve olayları içermektedir. ${ }^{8}$

Türk halk hikâyelerinde, hikâye kahramanı günlük hayatta zor rastlanabilecek idealist bir kişiliğe sahiptir. Hikâye kahramanının bu özelliği, halk hikâyelerinin konularını güzellik duygusundan ve yüceltilmiş düşüncelerden almasını sağlar. Hikâyeci olaylara akıl ve mantı̆̆ıyla bir çözüm bulamayınca hayal ve sembollerden faydalanır. Böylece hikâye kahramanı normal bir insanın yapabilecekleri yanında, arzu ettiklerini de gerçekleștirebilecek özelliklere sahip olur. Kendi içinde tutarlı olmak şartıyla halk hikâyelerinde her çeşit olay yer alabilir. ${ }^{9}$

Türk halk hikâyelerini âşıklar ya yaşanmış bir olaydan belli gelenekler doğrultusunda veya yaşadığı kabul edilen bir âşı̆̆ın hayatı ve maceralarını esas alarak oluşturmuşlar, bu konuları geliștirip işleyerek düzenlemişlerdir. Olayların sınıflandırılması veya sıraya konulması anlamına gelen "tasnif" terimi, Türk halk hikâyelerinin doğuşu hakkında önemli ipuçları vermektedir. Âşık, hikâyenin konusunu tespit ettikten sonra, geleneğe göre nelerin nesirle anlatılacağını, nerelere şiir konulacağını planlar. Bu planın ardından olay mantığını, hikâye tasnif geleneğini, dinleyici çevrelerinin istek ve eğilimlerini, kendi kabiliyetini ve hikâye anlatımında rastlanan hazır kalıpları kullanarak tasnifi tamamlar. ${ }^{10}$

\footnotetext{
6 Pertev Naili Boratav, Halk Hikâyeleri ve Halk Hikâyeciliği, Adam Yayınları, İstanbul 1988, s. 34.

7 Öcal Oğuz, Halk Hikâyeleri Tahlili, Kültür Bakanlığı Yayınları, Ankara 2008.

8 Fikret Türkmen. "Hikâye", Türkiye Diyanet Vakfı İslam Ansiklopedisi, c. XVII, s. 488.

9 Nurettin Albayrak, "Türk Halk Hikâyelerinin Genel Özellikleri", Osmanlı Araştırmaları XXVI, İst. - 2005. s. 17

10 Albayrak, “Türk Halk Hikâyelerinin Genel Özellikleri”, s.5
} 
Hikâyeyi modern anlamda değerlendiren araștırmacılar çoğunlukla Türk edebiyatında hikâye ve romanı Tanzimat'la başlatırlar. Ancak Türklerin bu türde, İslâmiyet'ten önceki dönemlere kadar giden bir geleneğe sahip olduğu bilinmektedir. İslâmiyet'in kabulünden Tanzimat'a kadarki dönem içinde ise hikâye tarzına uygun manzum ve mensur pek çok eser kaleme alınmıştır. Bunlar destanlara ve efsanelere kadar uzanan bir çizgide kısmen tercüme veya bir çeşit uyarlama yoluyla meydana getirilmiş, kısmen de şairlerin muhayyilesinden doğmuş veya bizzat yaşanmış olayların hikâyeyi çağrıștıran örnekleridir.11

Klâsik Türk edebiyatının bir türü olan manzum - mensur küçük hikâyeler, diğerlerine nispeten çok farklı özellik gösterirler. Bunların konuları daha gerçekçidir. Bir kişinin başından geçen ya da iki üç kişi arasında cereyan eden, zaman ve mekânı belli bu tür hikâyelerde olaylar İstanbul, Bursa, İzmir, Kastamonu, Konya vb. yerlerde ve çoğunlukla tarihi belli bir zaman diliminde gerçekleşir. Türk toplum hayatının belli bir cephesini göstermesi bakımından konu birliğine sahip bu tür hikâyelerin her biri aynı zamanda bir tarihî belge değeri taşımaktadır.

Tanzimat sonrası hikâye ve romancılığında bu tür eserlerin önemli ölçüde etkisi görülmektedir. Modern Türk Edebiyatında, hikâye ve romanın köklerinde Batılı örnekler yanında klâsik edebiyatın bu tür örneklerinin de etkisi bulunmaktadır.

Öte yandan halk hikâyeleri de, aynı dikkatle ve modern öykü tekniğiyle incelendiğinde, bunlarda tasvirlerin zayıf olduğu, doğa tasvirlerinin belli şemalar içinde sınırlı kaldığı, hareketli metinlerin anlatılmasında pek başarılı olunmadığı, kurmaca dünya yaratmaktan çok ders vermenin amaçlandığı görülecektir. Bu bakımdan halk hikâyeleri, devrinin sanat zevkini aksettiren belli bir formun dişına çıkamaz. Bu zevk, bu dikkat, bu dünyaya bakış tarzı, Divan edebiyatına vücut veren kültürden ayrı düşünülemez. ${ }^{12}$

Buraya kadar Türk hikâyeciliğinin geçmişten günümüze kadar yaşadığı tarihsel süreç böylece ele alındıktan sonra İzmir'de 1926 yllında yayımlanan romana geçebiliriz. Biçim itibariyle romandan çok hikâyeye, modern hikâyeden çok halk hikâyesine benzeyen eser, bu türlerin hepsinin özelliklerini taşıması bakımından ayrı bir öneme sahiptir.

11 Hasan Kavruk, "Divan Edebiyatında Hikâye" Türkiye Diyanet Vakfi İslam Ansiklopedisi, C.17, s. 491.

12 Kavruk, s.495. 


\section{Romanın Özeti}

İzmir ve Ege bölgesinin en zengini olan Yusuf Ağa, seksen yaşında, hasta bir adamdır. Ölmeden tek çocuğu ve varisi olan yirmi yaşındaki Ahmet'i çağırır ve ona sakın evlenme diye vasiyet eder ve ölür. Bütün miras kendisine kalan Ahmet, kısa süre sonra bu vasiyetin nedenini araştırır. Babasının uzun zamandır yanında bulunan evin yaşlı dadısı Ayşe Bacı'dan babasının gençliğinden itibaren üç evlilik yaptığını fakat hepsinde de aradığı mutluluğu bulamayıp ihanete uğradığını, bu yüzden oğlunun da kendi kaderini yaşamaması için böyle vasiyet ettiğini öğrenir. Bunun üzerine geçmişi olmayan bir esire ile evlenir. Bu evlilikten bir de kızı olan Ahmet Ağa aradığı mutluluğu bulur fakat vasiyeti çiğnemiş olur.

Bir gün şehirde dehşetli bir veba salgını başlar. Konağa da bulaşan hastalığa karşı hekim getirmeye giden Ağa'nın aniden geçici olarak kalbi durur ve yere yığılır. Öldü diye üstündekileri soyup mezarlıkta bir çukura atarlar. Burada bir süre sonra kendine gelen Ağa, başından geçenleri hatırlayıp ne yapacağını düşünürken ayağına takılan bir mücevher torbası hayatını değiştirir.

Hırsızların bıraktığı bu mücevher torbası ile hayatını rahatça geçirebileceğini düşünen Ağa, evine gitmez, biraz ortalıkta dolaştıktan sonra Manisa'ya gidip orada meşhur Pir Ahmet kahvesine takılır. Bir süre sonra konağının tavrını merak ederek tanınmamak için hoca kıyafeti giyip Ağa'nın eski bir arkadaşı sıfatıyla evine gider. Evdekiler Ağa'nın öldüğüne inanıp bir süre üzüldükten sonra normal hayatlarına dönmüşlerdir.

Akşam mahallenin küçük kahvesine gittiğinde kahvedekilerin aralarındaki konuşmalardan çocukluk arkadaşı Hasan ile karısının seviştiğini, yakında evleneceklerini öğrenir. Bir gün gizlice bahçeye girdiğinde bu duruma gözleriyle şahit olur.

Kendini belli etmeden konağa sık sık gelen Ağa, pahalı hediyelerle kendini sevdirir ve Hasan ile karısının dostluğunu kazanır. Bunların evlenmelerini de sineye çeken Ağa, düğün gecesi konakta büyük bir yangın çıkartarak intikamını alır. İçinde kızının da yanacağını ise kendine şöyle kabul ettirir:

“-Ah... Sen, sen de bir kadın olmayacak miydın? Sen de ihanet, riya ve hırs gibi sefil arzuları taşıyan ve rast geldiğini hırpalayan, ağlatan ve yakan bir şey olmayacak mıydın? O halde yan! Sen de yan! Sen de inle! Sen de haykır! Sen de kıvran, sen de geber!"13 $\mathrm{Bu}$ cümleler aslında romanın da özünü olușturmaktadır.

13 Raif Nezih, Ağanın Oğlu, s. 36. 
Fakat yağan aşırı yağmurun etkisiyle sığındığı Kadifekale'nin surları yıkılır ve Ağa altında mahsur kalır, kurtulmaya çalışır fakat kurtulamaz, sonunda geçici cinnet geçirip delirir ve Manisa tımarhanesine yatırılır.

Tımarhanenin görevlisi Keleşoğlu delilere karşı çok acımasız, karısı Gülsüm ise çok şefkatlidir. İlk geldiğinde epey dayak yiyen Ağa, daha sonra cinnet hali geçip kendine gelince buradan kaçmanın yollarını aramaya bașlar. Sonunda bir gece bir yolunu bulup kaçmayı başarır.

Ağa'nın Hasan ile karısının evlendikleri gece konakta çıkardığı büyük yangında evdeki herkes yanarak ölmüss, yalnızca Ağa'nın küçük kızı Zeliha, gözlerini kaybetmiş olarak kurtulmuştur. Hayatta kimsesi olmayan âmâ kızı İzmir'in kadısı Kadı Osman, çocuğun malına el koymak için yanına alır. Kadı Osman'ın evinde onun karıları ve çocukları tarafından devamlı tartaklanan ve aşağılanan Zeliha, dayanacak gücünün kalmadığı bir gece yarısı konakta büyük bir yangın çıkararak kendisiyle beraber Kadı Osman'ın bütün ailesinin yok olmasını sağlar.

Bir gün Akhisar'da Deli Murat'ın işlettiği büyük kahveye üstü başı harap bir adam girer. Bir şeyler anlatmak istediği belli olan bu adama sıcak içecek verip oturturlar ve nereden gelip nereye gittiğini sorarlar. Dilenci kılıklı adam: "Kim olduğumu, başımdan neler geçtiğini değil fakat vaktinizi hoşça geçirecek bir İzmir masalı söyleyeceğim: Bir varmış bir yokmuş" diyerek kendi hayatını anlatmaya bașlar. Herkes masal dinler gibi dinler fakat fazla etkilenmezler. Toplanan üç beş akçeyle adamı gönderirler. Kimse bu anlattıklarının gerçek olduğuna inanmaz, bu hikâye de kulaktan kulağa yayılır ama İzmir Ağa'sı art arda gelen bu felaketler sonucu unutulur.

Bir süredir ortalıkta görünmeyen Ahmet Ağa, bakımsız, dilenci kılıklı biri olarak Bursa'da ortaya çıkar. 0 gün Bursa'nın ağalarından Mustafa Ağa evlenmektedir. Dışarıdaki coşkuyu tıpkı kendi düğününe benzeten, bu coşkunun sonunda da kendi düștüğü felaketlerin aynen yaşanacağını düşünen dilenci kılıklı adam, bu evliliğe mani olmayı kafasına koyar ve bunun planını yapar.

Dügün gecesi camide yatsı namazından sonra çiftin mutluluğu için eller açlırken İzmir'in ağası birden bire ağaya kalkıp yüksek bir sesle:

-Durunuz, beni dinleyiniz! Diyerek kendi başından geçenleri anlatmaya başlar. Hikâye bitince güvey olan ağa, bu hikâyeden çok 
etkilenir ve ağlamaya başlar. Hatta zifaf odasına götürülürken kendisine yapilan teselliler bile fayda vermez.

Sabah olduğunda şehirde yeni evlenen ağa ile karısının hançer ile öldürüldüğü haberi duyulur fakat kimin yaptığı belli değildir. Zaptiye başı olay gecesi camide hikâye anlattığı için meczup kılıklı adamdan şüphelenip hapse atar. Orada suçunu itiraf etmesi için vurulan şiddetli kırbaç darbelerine dayanamayan İzmir'in bahtsız ağası ölür ve ebedi huzuru ancak böyle yakalar.

Olay şöyle meydana gelir. Camide dinlediği hikâyeden etkilenen güvey, gözleri yaşlı olarak içeri girer fakat konuşmak istese de konuşamaz. Karşısındakinin suskunluğundan da şüphelenip kendisinin aynı hikâyedeki ağa gibi aldatıldığını sanıp hançerle önce gelini sonra da kendisini öldürür. Hikâye, yazarın şu kısa değerlendirmesiyle biter:

"Ah ey kadın! Bazı gaddar olursun, bazı da iște böyle mağdur! Tarihin bu uzun ve olgun derinliklerinde hâlâ senin kanlı izlerin yaşıyor. Fakat sana kan kusturan afacanlar da eksik olmuyor. 0 halde sen nesin? Sen şusun ki: İyilik de fenalık da senin için yapılır... Sen biri melek biri şeytan olan bu iki yavrunun anasısın. Fakat babası da erkekler!

\section{Romandaki Halk Edebiyatı Unsurları}

Romanın başında, isminin hemen altında "Tarihi halk romanı" ifadesi yer almaktadır. Buradaki halk romanı ifadesiyle sanat kaygısı gütmeksizin, sürükleyici olaylarla geniş okur kitlelerinin ilgisini çekmek amacıyla yazılan romanlar kastedilmiştir. Buna göre değerlendirecek olursak Ağanın Oğlu romanına halk hikâyesi tadında bir tarihi halk romanı veya popüler roman diyebiliriz.

Tarihi roman türü, kişileri, konuları ve geçtiği zaman bakımından diğer romanlardan ayrılır. Konular ve kişiler, dolayısıyla mekânlar, tarihi olaylarla ilişkilidir. Bu tür romanlarda yazarlar hayal güçlerini kullanarak, olayın geçtiği tarihe uygun olarak hikâyelerini biçimlendirirler. Türün gereği olarak yazar hem bir tarihçi gibi hem de bir sanatçı gibi davranma zorunluluğundadır. Bu tür romanlar açısından her zaman tarihi karıştırma durumuna düşme tehlikesi vardır. ${ }^{14}$

Bu durum, yaşlı, bilge hikâye anlatıcıları için de geçerlidir. Yazıya geçirilmiş olan hikâyeler herkes tarafından okunabilir,

\footnotetext{
14 Erkan Erginci, "Halk Hikâyesi Anlatıcısı ve Romancı İlişkisi Bağlamında Murat Sertoğlu'nun Battal Gazi Romanı”, Milli Folklor, 2005, Yıl 17, Sayı 67, s. 2.
} 
ulaşlabilir hale gelince hikâye anlatıcılarının yerini yazarlar almaya başlamıștır. Halk hikâyeleriyle konu olarak da pek çok ortak yönleri olan tarihî romanlar için bu durum daha belirgindir.

$\mathrm{Bu}$ tarihi halk romanı türü eserlerde göze çarpan en belirgin özellik dildeki basitliktir. Karakterler çoğu zaman yüzeyseldirler ve daha çok tip olarak tarif edilirler. Hikâyeyi karakterler değil aksiyon sürükler. Psikolojik yönleri zayıf olan eserlerde kullanılan insani duygular genel anlamda aşk, sevgi, nefret, intikam, vatan sevgisi duyguları etrafında yoğunlaşır. Tarihi romanın başkişisi genelde varoluşunu sorgulayan bir kişi değil, Forster'in terimlerini kullanarak söylemek gerekirse, yuvarlak değil düz bir karakterdir ve bu yüzden romanın başında hangi özelliklere sahipse romanın sonunda da aynı özelliklere sahiptir. Roman, karakterin değișimini değil hareketlerini, yaptıklarını anlatır. ${ }^{15}$

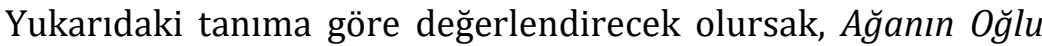
romanında nefret ve intikam duygusu öne çıkmaktadır. Hatta bu duygu o kadar öne çıkar ki Ağa intikamını evi yakarak alır, âmâ kızı Zeliha da Kadı Osman'ın evini bir gece yakarak kendisi de dâhil konaktaki herkesin ölümüne neden olarak intikamını alır. Kahramanın en öne çıkan özelliği intikam duygusudur. Eser, bu duygunun etkisiyle devam eder ve biter.

$\mathrm{Bu}$ konuda Alemdar Yalçın, tarihi romanlara yaklaşımı şu şekilde açıklıyor: "Haklı veya haksız olduklarını tartışmadan, yıllarca aydınlarımızın göz ardı ederek, küçümseyerek baktıkları Ebu Müslim, Battal Gazi, Zaloğlu Rüstem, Köroğlu gibi piyasa kitapları geniş kitlelerin kahramanlıklarını paylaşmak istedikleri insanların maceralarını anlattığı için tutulmuştur. Şurası bir gerçektir ki aydınlarımız batıda tarihi romana dönüş başlamadan önce geçmişe yönelmeyi hep küçümsemişlerdir."16

$\mathrm{Bu}$ alıntıda geçen efsanevi tarihi halk kahramanlarından Zaloğlu Rüstem aşağıda gelecek olan şiirde de geçmektedir. Bir halk kahramanı olan bu ismin şiirde kullanılması, yine tezimizi güçlendiren bir örnek olması bakımından önemlidir.

$\mathrm{Bu}$ eserle ilgili taradığımız kaynaklarda ayrıntılı bir bilgiye rastlayamadık. Fakat bugüne kadar birkaç araştırmacının ilgi alanına giren yazar ve eserle ilgili bazı bilgilere de ulaştık. Eserle ilgili ilk kaynakta şu bilgiler verilmiştir. "Vakası II. Mahmut devrinde geçen

15 Erginci, s.3.

16 Alemdar Yalçın, Siyasal ve Sosyal Değişmeler Açısından Cumhuriyet Dönemi Türk Romanı: 1920-1946, Akçağ Yayınları, Ankara 2002, s. 258. 
bu "tarihi halk romanı" şehrin en zengini olması dolayısıyla İzmir Ağası olarak tanınan Yusuf Ağa ile oğlu Ahmet'in birbirine çok benzeyen trajik hikâyeleri anlatılır. Her ikisi de hanımlarının ihanetine uğrayarak bedbaht olan bu iki kahramanın hikâyeleri çerçevesinde İzmir ve çevresinin adet ve geleneklerine dair birçok malzeme romanda kullanılmıştır. Bu bakımdan folklorik bir değeri olan eserde kadınlar çoğunlukla olumsuz bir bakış açısından görünürler"17

Romanla ilgili bulduğumuz ikinci bilgi ise Bilkent Üniversitesi'nde yaptırılmış olan bir tezdir. Burada da romanla ilgili şu bilgiler yer almaktadır. "Raif Nezih'in Ağanın Oğlu (1926) kitabı ise, "tarihi halk romanı" ibaresi taşımasına rağmen bugüne kadar fark edilmemiş tarihi romanlardan bir tanesidir. Ă̆anın Oğlu kitabı “Sultan Mahmud'un Hüsrev Paşa'ya öldürttüğü meşhur kâtip Mehmed Efendi'den evvel 1200 senelerinde İzmir'in sahipkıranı bir Yusuf Ağa vardı" cümlesiyle başlar. Bu kitabın tarihi bir diğer özelliği ise tarihi romanların tümü İstanbul'da basılırken, İzmir Bilgi Matbaası'ndan çıkmış olmasıdır. ${ }^{18}$ Buradaki bilgiler eseri görerek verildiği için doğru bilgilerdir.

Son olarak üçüncü bir kaynakta da şöyle bir bilgi mevcuttur: “1923 yılında Yelki Matbaası'nda basılan iç içe iki büyük hikâyenin birleşmesinden meydana gelen Ağanın Oğlu isimli romanda, bir ağa ile oğlunun kadınların ihanetine uğraması işlenmiștir" ${ }^{19}$ Burada verilen bilgide iki önemli okuma hatası yapılmıştır. Bunlardan biri romanın yayın tarihinin 1926 olmasına rağmen 1923 yazılması, ikincisi de yayınlandığı matbaanın Bilgi Matbaası olduğu halde yanlış okuma yapılarak Yelki Matbaası denmiş olmasıdır. Ayrıca bu eser, iki büyük hikâyenin birleşmesiyle oluşmamış, birbirine benzeyen iki hayatın bir bütünlük içinde anlatılmasıyla meydana gelmiştir.

1926'da eski harflerle yayınlanmış olan bu matbu eserin öncelikle türünün tespiti gerekmektedir. Ăganın Oğlu, tür olarak roman diye tanıtılsa da yapısı itibariyle daha çok hikâyeye benzemektedir. Şahıs kadrosu oldukça dar olup geriye dönüşler pek görülmez. Düz çizgi şeklinde akıp giden vaka tekdir ve baştan sona

17 Ömer Faruk Huyugüzel (Prof. Dr.), İzmir Fikir ve Sanat Adamları, Kültür Bak. Ankara 2000, s. 503.

18 İsmail Uygun, "Cumhuriyet Dönemi Tarihi Romanlar 1923-1946: "Eski" Kahramanların Yeni Söylemleri”, Bilkent Üniversitesi Sosyal Bilimler Ens. 2014, s. 81. (Yayınlanmamış Yüksek Lisans Tezi)

19 Turan Akkoyun (Dr), "Raif Nezih Atakul", Toplumsal Tarih Dergisi, Ocak 1997, S. 37, s. 54-57. 
aynı düşünceyi işler. İzmir ve çevresinin âdet ve geleneklerine dair birçok malzemenin kullanıldığı roman bu bakımdan folklorik bir değer taşımaktadır. Burada bu adet ve geleneklerle folklorik özellikleri gösterilmeye çalışılacaktır.

Bilindiği gibi Milli Edebiyat döneminden itibaren edebiyatta halka yönelme, milli ve yerli kültür değerlerinin işlenmesi, kısaca halka doğru anlayışı öne çıkmıştır. Bu anlayış milli mücadeleden sonra da devam etmiş, milli kültür olușturma kaygısı hep canlı tutulmuştur. Yazarın böyle bir romanı Cumhuriyetin ilanının hemen sonrasında yazmasının amacı edebi bir eser ortaya koymaktan çok halkın dikkatini çeken bir konuyu anlatıp onlardaki okumaya olan ilgiyi artırmaktır. Bu yönüyle romanın teması yeni Cumhuriyetin altı umdesinden "Halkçıllk" ilkesine uygundur.

Ağanın Oğlu romanında konu olarak kadınlara güven duyulmaması gerektiği dile getirilmiştir. $\mathrm{Bu}$ ana fikir etrafında gelişen olaylar romandaki baba Yusuf Ağa ve oğlu Ahmet Ağa'nın hayatına giren çeşitli kadınlar üzerinden verilmiștir.

Yazarın bu konuyu seçmesindeki amacı, halkı evlenmekten ve kadınlardan soğutup nefret ettirmek değildir. Çünkü romanda evlenip de bahtsız olan, ihanete uğrayan kişiler yalnız Yusuf Ağa, oğlu Ahmet Ağa ve Bursa ağası Mustafa Ağa'dır. Böyle ele alınmasının nedeni yazarın ağalık sistemi üzerinden eski Osmanlı yönetimine getirmek istediği eleştiridir.

Roman İzmir ağası Yusuf Ağa'nın abartılı mal varlığını sayarak başlar. Öyle ki Ağa, İzmir'in neredeyse tamamının sahibidir ve İstanbul'a tek başına gönderdiği vergi çok büyük bir yekûn tutmaktadır. Burada benzerine ancak masallarda karşılaşılabilecek zenginlik şöyle ifade edilir. "Şimdiki Hapishane, Damlacık, İki Çeşmelik, Çorak Kapı, Kaleiçi, Vezir Hanı ve hükümet konağı hudutları içinde büyücek bir kasabadan ibaret olan o zamanki İzmir, hemen de kâmilen bu Ăga'nın mülkü idi"20

$\mathrm{Bu}$ kadar zengin olan birisinin mükemmel değilse de en azından normal bir evlilik yapması beklenir. Fakat mal varlığı olarak normalin çok üstünde olan ağanın evlilik bakımından bahtsız olması, yazarın bu tiplerden intikam almak veya yeni Cumhuriyet'in yetiştireceği insanlar arasında bu tiplere yer olmadığını vermek istemesi olabilir. Ayrıca bu tema, her zaman tartışma konusu olan paranın mutluluk getirmediği tezine de uygundur.

20 Raif Nezih, Ağanın Oğlu, s. 1. 
Romandaki bu kadın şikâyeti Tanzimat romanlarında görülen erkek karakteri kurtarma motifi üzerine kurulan eserleri akla getirmektedir. Burada kadının tehlike olarak algılanışı öne çıkmaktadır. Tanzimat dönemi erkek karakterleri Ali Bey, Felatun Bey, Bihruz Bey gibi yitik karakterler, tehlikeli kadın kurbanı olarak realist halk hikâyeciliğini devam ettirirler. ${ }^{21}$

Halk hikâyesi tadında anlatılan, diyalogların çok az olduğu, abartılı benzetme ve betimlemelerle süslenen romanda Türk romanlarının olmazsa olmazı olan kahramanların âşık olması teması yoktur. Hem Yusuf Ağa hem de oğlu Ahmet Ağa yaptığı bütün evliliklerde âşık olmamışlar, hanımları tarafından bile sevilmemişlerdir. Bu durumun halk hikâyelerinin genel özelliklerine aykırı olduğu gibi, romanlarda da bu kadar aşksız bir örneğine rastlamak pek mümkün değildir.

Romanı benzediği halk hikâyesi unsurları bakımından değerlendirecek olursak en başta ele almamız gereken konu kahvehanelerdir. Sonra diğer unsurlar gelir.

1) Kahvehaneler: Kahvehaneler, tarihi seyri içinde âşıklık geleneğinin en önemli icra mekânlarından ve Osmanlı toplumunda halkın sosyalleşmesinin en temel kurumlarından biridir. Buralar meddahların, kuklacıların, halk hikâyesi anlatıcısı olan âşıkların sık uğradığı mekânlardır. Özellikle 17. yy.dan itibaren büyük şehirlerde ve yerleşim yerlerinde açlan âşık kahvehaneleri bu tür faaliyetlerin merkezi olmuşlardır. Yine bu yüzyıldan itibaren pek çok ünlü âşıklar, başta İstanbul olmak üzere büyük şehirlerin âşık kahvehanelerinde çalıp söylemişler, geniş halk kitleleri tarafından tanınmalarını burada sağlamışlardır.

Fuad Köprülü, 18. yy.da saz şairlerinin kahvehanelerde ellerindeki sazlarıyla şiirler söylediğini, bu yıllardan itibaren saray tarafından âşıkların kontrol altında tutmak için âşık kethüdalığı kurduklarını ve otuz kadar aşığın saray tarafından maaşa bağlandığını belirtir. ${ }^{22}$ Âşıklar kethüdalığının Sultan II. Mahmut tarafından kurulduğuna ve Sultan Abdülaziz'in bizzat kahveye giderek, bazen de saraya davet ederek âşıkları dinlediğine bakılırsa 19. yüzyılda âşıı kahvelerinin İstanbul'da oldukça revaçta olduğu

\footnotetext{
${ }^{21}$ Nuran Kekeç, 'Sözlü Edebiyattan Tanzimat Romanına Giderken 'Anlatı', 'Anlatıcı' Ve 'Așk Olgusu'nun Dönüşümü”, Millî Folklor, 2011, Yıl 23, Sayı 92, s. 5.

22 M. Fuad Köprülü, Türk Saz Şairleri, 5. cilt, Ankara 1964.
} 
anlaşılır. ${ }^{23} \mathrm{Bu}$ dönemde sadece İstanbul'da değil, Anadolu'nun belli başlı kültür merkezlerinde de âşık kahvehanelerinin sayısı artmıștır.

Konusunu II. Mahmut döneminde İzmir'de yaşanmış olaylardan alan bu kısa romanın içinde birden çok yerde kahvehane ismi geçmektedir. $\mathrm{Bu}$ yönüyle de eser halk hikâyesine benzemektedir. İzmir, Manisa, Akhisar ve Bursa'da Ahmet Ağa'nın çeșitli kahvelere devam etmesi, Ağa'nın bazı bilmediklerini kahvelerdeki konuşmalardan öğrenmesi, son olarak da dilenci kıyafetiyle başından geçenleri hikâye tadında kahvehanelerde halka anlatması bu eseri halk hikâyesine benzetmektedir. Bu durum yazarın hem halk hem de kahvehane kültüründen haberdar olduğunu, eserin ise modern romanın halk hikâyesi motifleriyle farklı bir özelliğe büründürülmek istendiğini göstermektedir.

Örneğin, romanda geçen ilk kahvehane için şu ifadeler yer alır: "İçeriye giren yabancının selamını koyu dumanlar fişkıran çubuklarını ağızlarından çıkarmadan aldılar. Vakit yatsıyı biraz geçmişti. Manisa'nın bu meşhur Pir Ahmet kahvesinde şehrin belli başlı ihtiyarları keyiflerini çatıyorlardı. Yabancı kapı yanı bir minderin üstüne diz üstü oturdu. 0 zaman fakir ve garip olanlar böyle oturur, köșe minderlerine bağdaş kurmuş ağniyanın hitabına mazhar olmadıkça ağız açmazlardı. Bu devirlerin fakirlerle zenginleri kahvehanelerde bir araya getiren güzel bir itiyadı vardı. Fakat buralarda bir tutam bıyıkları olmayanlar bulunmazdı."24 Görüldüğü gibi yazar burada yalnız kahvehaneden bahsetmez, oradaki oturma adetlerinden de bahseder.

Kahvehanelerle ilgili ikinci örnek ise şöyledir: "O gece mahallenin küçük kahvesinde Hasan'ın kurtulduğunu öğreniyordu. Ağa bu dedikoduları ufak kahvenin orta halli insanlarından dinliyordu. Ve sonra içlerinden biri iki telli sazını alarak çalmaya başladı." 25 "Her akşam yine ufak kahvenin dumanları arasında, o aşığın sazını dinlemeye gidiyordu. Buranın müdavimleri hep eskiden tanıdı̆̆ı ve bazısına ekmek yedirdiği adamlardı. İçlerinde akarının kiracısı olanlar da vardı. Fakat hiç biri bu dertli Hoca'nın, vebadan ölen İzmir Ağa'sı olduğunu bilmiyordu."26

\footnotetext{
${ }^{23}$ M. Nazmi Özalp, “Osmanlı Döneminde Türk Musikisi”, Türk Yurdu, cilt: 19-20, sayı 148-149, Aralık 1999 - Ocak 2000.

${ }^{24}$ Raif Nezih, Ağanın Oğlu, s.26.

${ }^{25}$ Ağanin Oğlu, s. 30

${ }^{26}$ Ağanın Oğlu, s.32
} 
Bu örneklerde de kahvedeki bir aşığın halkı etkileyen olay üzerine sazını çalıp söylemesi, âşıkların kahvehanelerdeki durumuyla birebir benzemektedir.

Son olarak romanda geçen üçüncü kahvehane, Ağa'nın tımarhaneden kaçıp dilenci kılığında gezdiği sırada uğradığı kahvehanedir. Bu örnek de âşıklar tarafından kahvelerde halk hikâyesi anlatımına güzel bir örnektir.

"Akhisar'ın büyücek kahvesini Deli Murat işletiyordu. Tiryakilerin sedirlere yaslanıp, çubuklarını tüttürdükleri bir akşam, üstü başı harap bir dilenci bu kahvenin kapısından içeri girmişti. Kim olduğumu, başımdan neler geçtiğini değil fakat vaktinizi hoşça geçirecek bir İzmir masalı söyleyeceğim: Bir varmış bir yokmuş... Diye tutturarak bütün başından geçenleri anlattı. İhtiyarlar buruşuk gözlerini kırparak çubuklarını sık sık, derin derin çekerek, orta yaşlılar ağzına girecek gibi eğilerek dilenciyi dinlediler. Sonra tuttular, Deli Murat'ın gezdirdiği tepsiye birkaç akçe bıraktılar ve bir masal kahramanı gibi sözlerini bitiren dilenci, yine bir masal kahramanı gibi çekildi gitti."27

2) Halk Türküleri: "Türk halk şiirinde sosyal konular, insanların çeşitli nedenlerle çektikleri acılar, bu arada kadının toplum içindeki yeri dolayısıyla katlandığı eziyetler özellikle anonim ürünlerde sık rastlanan konulardandır." 28 Burada kısa dörtlüklerle ve halkın diliyle ifade edilen olaylar, halk şiirinin dar kalıpları içinde ancak bu kadar güzel ifade edilebilir.

Romandaki halk türkülerinin söyleyeni belli değildir. $\mathrm{Bu}$ yüzden anonim olarak değerlendirilmektedir. Fakat söyleyișteki basitlik, kafiye düzenindeki acemilik, kelime seçiminde düşülen tekrarlara bakılırsa bu şiirler usta bir aşığa ait değil, belki yazarın bizzat kendisi tarafından romanı yazarken aceleyle karalanmış sözler olduğu düşünülebilir.

$\mathrm{Bu}$ romanın halk edebiyatı anlatı formuna benzeyen önemli özelliklerinden biri de kısa vakanın içinde dört tane anonim halk türküsünün yer almasıdır. Devamlı halkın gözü önünde olan ve yaptığı yardımlarla büyük sevgi ve saygı duyulan Ağa'nın başına gelen her olumsuz durum halkı üzmüș, ona uygun bir türkü yakılmıştır. Bu yakılan türkülerden ilki şöyledir:

Ağam ağam, benim ağam...

\footnotetext{
${ }^{27}$ Ağanın Oğlu. s. 45.

${ }^{28}$ Doğan Aksan, Halk Şiirimizin Gücü, Bilgi Yayınevi, Ankara 2005, s. 45.
} 


\section{Ben olamam senin, ağam \\ Sonra sana (Demir) ağam \\ Kiyar elbet bir gün olur... \\ Vazgeç ağam bu sevdadan \\ Gönlüm, ona vurgun inan \\ Ayıplasin, varsin duyan \\ Ben olamam senin ağam}

Bu türkü Yusuf Ağa'nın, daha yirmi yaşlarında "ateşli bir genç iken" Aydın Beyi Hasan Ağa'nın kızı Zehra ile yaptığı evlilik ve sonrası geliş̧en olayların arkasından Zehra'nın ağzından söylenmiştir. Zehra, Ağa'nın konağına gelin geldiği günün akșamı babasının kâhyasının oğlu ve eski sevgilisi Demir tarafından kaçırılmıştır. Kendisi belki mutlu olmuş ama bu olay Ağa'nın ilk ihaneti yaşadığı evlilik olmuştur. Bu türkü onun ağzından Ağa'ya, sevenleri ayırmak mutluluk getirmez anlamında söylenmiş bir türküdür.

Hece vezninin $4+4=8$ kalıbıyla yazılan ve aaab / ccca biçiminde kafiyelenen şiir, dil olarak da oldukça sadedir ve halk șiirinin bütün özelliklerini taşımaktadır. Şiirde ahenk "ağam" kelimesinin tekrarı ve "-an" harfleriyle yapılan tam kafiye ile sağlanmıștır. Şiirde "senin olmak, cana kıymak ve vurgun olmak" gibi halk deyimlerine de yer verilmiștir. Türkünün yapısına ve acemice kurgusuna bakıldığında usta bir âşık tarafından değil, halk ağzından söylendiği bellidir.

Eserdeki ikinci türkü de şöyledir:

Kadının fendine akıl erişmez

Zaloğlu Rüstem'le bile sevişmez

Saruhan güzeli yamandır, yaman

Bir değil uğruna, binlerce yanan

$\mathrm{Al}$ atın üstünde cirit oynarsın

Diş ehli fendine neden kanarsın

Yine bir başkasıyla evlenme sakın

O dertsiz başını nâra yakarsın

İlk evliliğinden umduğunu bulamayan Ağa, aradan on yll geçtikten sonra yaşadıklarının halk arasında unutulduğunu düşünüp tekrar evlenmeye karar verir. Saruhan beyi Mustafa Ağa'nın kızı Zeynep istenir ve gösterişli bir dügün yapılır. Fakat aradan altı ay 
geçmeden Zeynep bir çocuk düşürür. Bundan şüphelenen Ağa, kızı babası evine gönderir ve bir kez daha bahtsız olur. Bunun üzerine halk arasında bu türkü gizliden gizliye söylenir.

Hecenin $6+5=11^{\prime} l i$ kalıbıyla yazılmış ve aabb / ccdc biçiminde kafiyelenmiş olan bu ağıt türündeki şiirde ahenk birinci dörtlükte ilk iki mısrada -iş harfleriyle, üçüncü ve dördüncü mısralarda ise -an harfleriyle tam kafiye yapılarak sağlanmıştır. İkinci dörtlükte ise birinci, ikinci ve dördüncü mısralarda "-ar" harfleriyle yapılan tam kafiye ile sağlanmıştır.

Şiirin dili sade olmakla birlikte halk arasında da kullanılan "fend, nar" gibi yabancl; dişi, sevişmek gibi argo kelimelere yer verilmiştir. Bu manzumede de "başını nara yakmak, kadının fendine akıl ermez" gibi deyimler kullanılmıştır. Efsanevi bir halk kahramanı olan "Zaloğlu Rüstem" ismi ise halk kültürü etkisini daha fazla göstermesi bakımından dikkat çekicidir.

Romanda geçen üçüncü türkü, öldügü sanılıp arkadaşı Hasan’la evlenmeyi düşünen Esire için kahvede bir âşık tarafından saz eşliğinde söylenen türküdür.

Kimlere bıraktın gittin onu sen
O kahpe dinli pek çıtı çileden
Avradın çıkar mı hiç vefalısı
Ah ağam seninki pek belalısı
Eloğlu abayı yaktı karına
Yosmanın gitmiyor bu iş arına
Gel ağam gel de gör telli gelini
Kahpenin bağrına sok hançerini

Daha önceki iki türkü baba Yusuf Ağa'nın uğradığı ihanet üzerine yazılmışken, bu şiir oğul Ahmet Ağa'nın düştüğü aynı durum için söylenmiştir. Hecenin $6+5=11^{\prime} l i$ kalıbıyla yazılmış, aabb / ccdd biçiminde kafiyelenmiş olan bu şiirde de ahenk ikişerli mısralar arasında yapılan kafiyelerle sağlanmıştır. Şiirin birinci dörtlüğünde ilk iki mısrada -en harfleriyle üçüncü ve dördüncü mısralar arasında vefa - bela kelimeleri arasında uzun -â harfiyle tam kafiye yapılmıştır. İkinci dörtlükte de aynı durum tekrar etmiş, ilk iki mısradaki -karı, -arı kelimelerindeki -arı harfleriyle zengin ve tunç kafiye yapılmış, üçüncü ve son mısralar arasında ise -gelini / hançerini kelimelerindeki "-in" harfleriyle tam kafiye yapılarak kulağa hoş gelmesi sağlanmıştır. 
Șiirin dili oldukça sade olup "kahpe dinli, yosma, avrat" gibi argo kelimeler kullanılmıștır. Ayrıca "abayı yakmak, arına gitmek, bağrına hançer sokmak" söz kalıpları veya halk deyişlerine yer verilmiştir.

Romandaki dördüncü ve son türkü, Ağa'nın gözleri görmeyen kızı Zeliha'nın kendisiyle birlikte Kadı Osman'ın evindekilerin hepsini yaktığı yangının arkasından söylenmiş, uzun olduğunu sandığımız şiirin romana yalnız bir kıtası alınmıştır.

Anan gitti, baban gitti, sen gittin

Duramadin artlarınca seyrettin

Necep kıydı yangın tatlı canına

Neden girdi ecel senin kanına

$\mathrm{Bu}$ şiir de hecenin $4+4+3=11^{\prime}$ li hece vezniyle yazılmış, aabb biçiminde kafiyelenmiştir. Burada da şiirde ahenk kafiye ile sağlanmış, ilk iki mısradaki -gittin / -seyrettin kelimeleri arasında -t harfiyle yarım kafiye yapılmış, üçüncü ve dördüncü mısralardaki can / -kan kelimeleri arasında -an harfleriyle tam kafiye yapılmıștır. Ayrıca burada da "kanına girmek, ardınca seğirtmek" gibi söz kalıplarına yer verilmiş, halk dilinde "ne acaba (acep)" kelimelerinin birleşmiş hali olan "necep" kelimesi kullanılmıștır.

Görüldüğü gibi romanın içinde, önemli bir olaydan sonra halk ağzıyla söylenmiş bir anonim türküye veya şiire yer verilmesi romandaki halk edebiyatı etkisine önemli bir örnektir.

3) Diğer Unsurlar: Dil ve üslup olarak da romanda birçok halk deyişlerine rastlanmaktadır. Bunlar halk deyimleri, argo kelimeler ve abartılı ifadelerdir. Halk deyimleri olarak romanda geçenler: "Sıtmanın yanında baş ağrısı mühimsenmez, kırk bin kere maşallah, buzağıya tapınan zenciler gibi" örneklerin yanında "Kırk gün kırk gece düğün yapmak", "şehrin halkının ekseriyetle Ağa'nın ekmeğiyle geçinen insanlar" olması, "Ağa'nın servet ve nüfuzuna payan" olmaması, "huddam ve cevarisi (hizmetçi ve cariyeleri) bine yakındı" gibi abartılı sözler de az değildir.

Son olarak romanda birçok argo ve küfür denilebilecek halk ifadeleri de mevcuttur. Bunlar rastgele değil, konunun uygunluğuna göre seçilmişledir. "Kahpe dinli, kahpenin avradı, yosma, yüzüne tükürmek, zenan, kocakarı, piç, mercimeği fırına vermek" vb. örnekler sıklıkla kullanılmıștır. Yazar bu ifadeleri kullanırken 
herhangi bir açıklama veya pişmanlık belirten bir ifade kullanmamıștır.

Türk romanında en çok Tanzimat romanında karşılaştığımız, genel olarak olumsuzluklarının anlatılıp eleştirildiği kölelik veya cariyelik kavramına bu romanda da rastlanmaktadır. Yazar, tarihi dönemine uygun olarak bu konuya değinirken, Tanzimat romanlarındaki yaklaşıma uygun hareket eder. Ağa'nın bir esire ile evlenmek istemesi üzerine kendisine gösterilen köle kızların teşhir sahnesi "Her bucaktan esir satıcıları, her çehrede ve güzellikte esirlerle İzmir'e gelerek Ağa'nın konağına varıyorlar, elini, yüzünü, saçını ve gerdanlarını açarak, bedbaht mallarını gösteriyor, beğendirmeye çalışıyorlardı."29 İfadeleriyle verilmiştir. Bunlardan Ağa'nın beğenip bir servet vererek satın aldığı cariyenin özelliği ise yine Tanzimat romanlarındaki tasvirlere benzemektedir. "Esire, beyaz tenli, kumral saçll, koyu mavi gözleri, gür ve uzun kirpiklere bürünmüş enfes bir Gürcü güzeliydi. Börümcek entarilerin içinde letafeti daha artmış, daha dayanılmaz ve duyulmaz bir hale gelmişti." 30

Bütün bunlardan ayrı olarak romanda çok zengin olan Ağa'nın hastalanıp öldü diye mezara atıldıktan sonra kendine gelince evine gitmeyip farklı bir hayatı yaşamaya başlaması gibi akıl dışı olaylara da yer verilmesi, masallarda görülebilecek motiflere örnektir ve romanı halk edebiyatı formuna daha çok yaklaştırmıştır.

\section{Sonuç:}

Raif Nezih Atakul tarafından yazılmış ve 1926 yılında İzmir'de yayınlanmış olan Ağanın Oğlu isimli kısa roman, içinde birçok halk hikâyesi biçim özellikleri göstermesi bakımından ilgi çekicidir. Buraya kadar olan değerlendirmemizde bu benzerlikler örneklerle gösterilmiştir. Bu güne kadar yeni harflerle basımı yapılmamış olan romanın edebiyat dünyasınca bilinmemesi doğaldır. Romanın ayrıca şahıs kadrosu, zaman, mekân, dil ve üslup özellikleri ve bilhassa içerdiği mahallî unsurlar bakımından ayrıca incelenmesi gerekir.

\footnotetext{
${ }^{29}$ Ağanın Oğlu. s. 17.
}

30 Ağanin Oğlu. s. 18. 


\section{KAYNAKLAR:}

1- AKKOYUN, Turan "Raif Nezih Atakul", Toplumsal Tarih Dergisi, Ocak 1997, S. 37, s. 54-57.

2- AKSAN, Doğan Halk Şiirimizin Gücü, Bilgi Yay. Ankara 2005, 2. b. $245 \mathrm{~s}$.

3- AKTAŞ, Şerif Roman Sanatı ve Roman Incelemesine Giriş, Akçağ Yay. Ankara 1991, 2. b. 161 s.

4- ALBAYRAK, Nurettin, "Türk Halk Hikâyelerinin Genel Özellikleri, Tasnifi ve Taş Baskısı Halk Hikâyelerine Bazı Katkılar", Osmanlı Araștırmaları XXVI, İst. 2005.

5- ALPTEKİN, Ali Berat Halk Hikâyelerinin Motif Yapısı, Ankara, 2003.

6- ARTUN, Erman Âșıklık Geleneği ve Âşık Edebiyatı, Karahan Yayınevi Adana 2014.

7- ATAKUL, Raif Nezih Ağanın Oğlu, Bilgi Matbaası İzmir 1926, $78 \mathrm{~s}$.

8- BORATAV, Pertev Naili, Halk Hikâyeleri ve Halk Hikâyeciliği, Adam Yayınları, İstanbul 1988.

9- ERGİNCİ, Erkan "Halk Hikâyesi Anlatıcısı ve Romancı İlişskisi Bağlamında Murat Sertoğlu'nun Battal Gazi Romanı", Milli Folklor, 2005, Yll 17, Sayı 67.

10- FİLIZOK, Rıza, Şiirimizde Halk Edebiyatı Tesirleri Üzerine Notlar, Ege Ün. Basımevi, İzmir 1999.

11- GÜNDÜZ, Osman Geleneksel Anlatım Formlarından Çağdaş Romana, Turkish Studies, International Periodical For the Languages Literature and History of Turkish or Turkic, Volume 4 /1-I Winter 2009.

12- HUYUGÜZEL, Ömer Faruk, İzmir Bilim ve Sanat Adamları, Kültür Bakanlığı, Ankara 2000, 550 s.

13- KAVRUK, Hasan, Divan Edebiyatında Hikâye Türkiye Diyanet Vakfi İslam Ansiklopedisi, C.17, s. 491.

14- KEKEÇ, Nuran, "Sözlü Edebiyattan Tanzimat Romanına Giderken 'Anlatı', 'Anlatıcı' Ve 'Așk Olgusu'nun Dönüşümü”, Millî Folklor, 2011, Yil 23, Sayı 92

15- KÖPRÜLÜ, M. Fuad, Türk Saz Şairleri, 5. cilt, Ankara 1964.

16- OĞUZ, Öcal Halk Edebiyatı El Kitabı, Grafiker Yayınları, Ank. 2007, 550.s.

17- __, OĞUZ, Öcal, Halk Hikayeleri Tahlili, Kültür Bakanlığı Yayınları, Ankara 2008. 
18- ÖZALP, M. Nazmi, "Osmanlı Döneminde Türk Musikisi", Türk Yurdu, cilt: 19-20, Sayı 148-149, Aralık 1999 - Ocak 2000.

19- ÖZGÜL, M. Kayahan, "Hikâyenin Romanı", Hece Dergisi Türk Öykücülüğ̈̈ Özel Sayısı, S. 46-47, Ekim- Kasım 2000.

20- SAÇKESEN, Ahmet, İzmir'de Yaşayan Âşlklardan Derlenen Halk Hikâyeleri Üzerine Bir Araştırma, Ege Ün. Sosyal Bilimler Enstitüsü 2003, (Yayınlanmamış Yüksek Lisans Tezi)

21- TÜRKMEN, Fikret, Hikâye, Türkiye Diyanet Vakfi İslam Ansiklopedisi, c. XVII, s. 488.

22- UYGUN, İsmail, Cumhuriyet Dönemi Tarihi Romanları 19231946: "Eski" Kahramanların Yeni Söylemleri, Bilkent Üniversitesi, Sosyal Bilimler Enstitüsü 2014, (Yayımlanmamış Yüksek Lisans Tezi)

23- YAZAR, Sevtap, "Destan, Halk Hikâyesi ve Masal Arasındaki İlişkiler ve $\mathrm{Bu}$ Unsurların Destanlara Yansıması" (http://web.deu.edu.tr/ ilyas/edebiyat/destan.htm)

24- YALÇIN, Alemdar, Siyasal ve Sosyal Değişmeler Açısından Cumhuriyet Dönemi Türk Romanı: 1920-1946, Akçağ Yayınları, Ankara 2002. 